\title{
On Demographic Change and Competitive Equilibrium in American Politics
}

\author{
Joshua N. Zingher \\ Old Dominion University
}

In their seminal analysis of American elections, Stokes and Iversen (1962) demonstrated that each party's share of the vote never strays very far from a competitive equilibrium. However, it is difficult to envision how this equilibrium will maintain amid changing demographics. The Republican leaning white proportion of the electorate is shrinking while the Democratic leaning Latino and Asian proportion is rapidly growing. These demographic changes threaten to tip the partisan balance in favor of the Democrats. Can the competitive equilibrium hold amid changing demographics? I answer this question in three steps. First, I analyze presidential election returns since the end of the Civil War. I confirm the presence of a competitive equilibrium. I then use a set of simulations to establish that demographic changes will tip the partisan balance in favor of the Democrats. I then assess how much the Republican Party will have to increase its level of support among whites and/or other groups to remain competitive. I find that relatively modest changes in white and/or Latino and Asian voting behavior will be sufficient to give the Republican Party an even chance of winning well into the future.

The author would like to thank Michael D. McDonald for his guidance on the initial versions of this paper. The author would also like to thank the two anonymous reviewers for their thoughtful suggestions.

In the wake Barack Obama's 2012 victory many within the Republican Party were deeply troubled. It was not even the fact that Republican challenger Mitt Romney lost that was so troubling; rather it was how he lost. Romney faired well among white voters, winning over 60 percent of the white vote. Romney's success among white voters was mirrored by his struggles among ethnic and racial minorities. Romney won a mere 1 percent of the African American vote and only 28 percent of the Latino vote. While the Republican Party's reliance on whites is nothing new, what has Republican elites worried is that ethnic and racial minorities constitute a growing proportion of the electorate. The importance of this trend is evidenced by the fact that Romney outperformed George W. Bush (not to mention McCain and Dole) among whites, yet unlike Bush, Romney lost decisively. Whites made up 72 percent of the electorate in 2012, down from 74 percent in 2008 and 77 percent in 2004. Whites will likely make up less than 70 percent in 2016. The Republican Party must find additional sources of electoral support. Otherwise, the Republican Party is faced the prospect of being relegated to a national-level minority.

So what are the odds that demographic shifts will actually reduce the Republican Party to a permanent minority? This possibility does not comport well with what we know about presidential elections. One of the most remarkable facets of American presidential elections is how competitive they are. The pattern of partisan wins and losses since the end of the Civil War is statistically indistinguishable from a coin flip. This parity led Stokes and Iversen (1962) to claim that the American party system is characterized by the presence of a competitive equilibrium where each party has a equal chance of winning any given election (also see: Bartels 1998; Erikson, Stimson and MacKuen 2002; Wlezien 2000; Wlezien and Erikson 2002; McDonald and Best 2006; Robbins and Norpoth, 2010; Mayhew 2011; Erikson and Wlezien 2012). The existence of this competitive equilibrium casts doubt on the possibility that changes in demography will create a sustained period of Democratic dominance. However, this does imply Republican Party will have to find new sources of electoral support to offset the shrinking white population. So what types of behavioral shifts will be sufficient? 
In this analysis, I assess the potential political consequences of changing demographics as well as estimate the types of behavioral changes that would have the effect of offsetting the declining size of Republican Party's base. My effort proceeds in five sections. First, I review the commentary on demographic change and outline the competing claims about its potential effects. Second, I evaluate the plausibility of these competing claims with a replication and extension of Bartels' (1998) analysis of competitive equilibrium in presidential elections. I find that over the long-term the electoral balance returns to the 50:50 mark, although over the short-term partisan tides can move the equilibrium in favor of one party over the other. Third, I simulate what the party system would look like if the current electoral trends were to continue. Using Monte Carlo simulations, I demonstrate that demographic changes will move the electoral equilibrium in favor of the Democratic Party if there are no countervailing shifts in electoral behavior. Fourth, I explore the size of the change in the Republican share of the white and/or Latino and Asian vote would be sufficient to maintain the equilibrium. I find that relatively modest changes in white and/or Latino and Asian voting behavior will be sufficient to give the Republican Party an even chance of winning future presidential elections. This finding is important because it demonstrates the competitive equilibrium is resilient to potentially disruptive large-scale demographic changes Finally, I conclude with some remarks about the plausibility of these various scenarios.

\section{The Relationship between Demographic Change and Party System Change}

Scholars have long wondered about the relationship between demographic and partisan change. Kristi Andersen was one of the first to note the connection between changing demographics and the changing electoral fates of the American political parties. In her book The Creation of a Democratic Majority, 1928-1936 Andersen (1979) laid out how immigrants from Southern and Eastern Europe dramatically reshaped the demographic composition of American cities and ultimately the American political coalitions. The Democratic Party, led by Al Smith in 1928 and Franklin D. Roosevelt in 1932 were able mobilize vast numbers of these first and second generation immigrants in Midwestern and Northeastern cities. The Democrats' success was based not on converting former Republicans but on mobilizing a previously untapped pool of voters. The Democrats used this strategy to successfully reverse a long period of Republican control of the presidency and Congress.

There are a number of parallels between the modern demographic and political context and those of the late 1920s and early 1930s. The last several decades have been marked by rapid demographic changes, which have dramatically reshaped the composition of the US electorate. Non-Hispanic whites comprised 63 percent of the population and 72 percent of the electorate in 2012, down from 74 percent in 2008 and 77 percent in 2004. Non-white voters represented 28 percent of the electorate in 2012, up from 26 percent in 2008 and 23 percent in $2004 .{ }^{1}$ These demographic trends are going to continue to transform the ethnic and racial composition of the electorate in the coming decades (Bowler and Segura 2012; Tichenor 2009). According to projections made by the Census Bureau, in 2032 non-Hispanic whites are projected to comprise

\footnotetext{
${ }^{1}$ These data come from Voter News Service national exit polling. The reported vote percentages are two-party vote percentages
} 
on 54.6 percent of the population - an 8.4 percent decrease. ${ }^{2}$ Latinos are projected to make up 23 percent of the population in 2032, a $43.75 \%$ increase from 2012.

The reason why these demographic changes are political significant is because these demographic groups have very different political preferences. I display the Republican share of the two-party vote in each presidential election spanning 1980 through 2012 for the country's major ethnic and racial groups in Table 1, as reported in Zingher's (2014,10-11) analysis of ANES survey data. The 2012 election was a particularly concerning defeat for the Republican Party-Mitt Romney won 60 percent of the white vote, the highest level of white support for a Republican since Ronald Reagan's landslide win over Walter Mondale in 1984, yet Romney lost decisively. ${ }^{3}$ The Republican Party lost despite a strong showing among whites in part because whites are making up a smaller proportion of the electorate. The Republican Party has been very successful in attracting white voters, winning nearly 60 percent of the white two-party vote in every election outside the two where Bill Clinton (and Gore in 2000, to a lesser extent) managed perform. Yet, the Republican Party has been less successful in courting ethnic and racial minority voters. On average, the Republican Party has managed to win just over a third of the Latino and Asian vote since 1980. George W. Bush managed to set the recent high water mark in 2000, capturing 43 percent of the vote. ${ }^{4}$ However, more recent Republican candidates have fared considerably worse among these emerging groups. Unsurprisingly, the vast majority of African Americans have not supported the any Republican candidate over the past thirty years. The highwater mark for black Republican support was 12 percent in 1984.

Table 1: Republican Share of the Two-Party Vote 2000-2012 (as reported by Zingher 2014)

\begin{tabular}{l|ccccccccccc}
\hline & 1980 & 1984 & 1988 & 1992 & 1996 & 2000 & 2004 & 2008 & 2012 & Mean & S.D \\
\hline White & 65 & 67 & 63 & 53 & 55 & 58 & 61 & 62 & 62 & 61 & 4.30 \\
African American & 6 & 12 & 9 & 7 & 1 & 8 & 12 & 1 & 1 & 6.3 & 8.17 \\
Latino/Asian/Other & 44 & 48 & 31 & 35 & 24 & 43 & 42 & 33 & 28 & 36.4 & 4.47 \\
\hline
\end{tabular}

The ramifications of how these disparities in party loyalty will affect the party system when they are combined with demographic changes have not been lost to observers. Over the last several years a considerable amount of trenchant popular commentary has arisen surrounding what affect America's changing demographic landscape will have on the fates of the parties. The question among scholars and observers is whether these changing demographics will create a long-term advantage for the Democratic Party.

\footnotetext{
2 Source: U.S. Census Bureau "Methodology and Assumptions for the 2012 National Projections" Table 9. http:// www.census.gov/population/projections/files/methodology/methodstatement12.pdf

${ }^{3}$ Source: http://www.washingtonpost.com/blogs/the-fix/wp/2012/11/08/president-obama-and-the-white-vote-noproblem/

${ }^{4}$ The estimated level of Latino and Asian support for Reagan was also in the 40 percent plus range, however, these estimates should be taken with a grain of salt. Latinos and Asians made up a very small proportion of the electorate during this time period; therefore, it is likely that there is a considerable amount of sampling error associated with these estimates. Moreover, the levels of Latino support for George W. Bush recorded in the 2004 exit polling have been shown to be inflated, so they should be interpreted with a grain of salt.
} 
The claim that demographic changes will bring about a sustained period of Democratic advantage is rooted in the partisan preferences of rapidly growing ethnic and racial minority groups. As Table 1 demonstrates, an often-considerable majority of Latinos and Asians have supported the Democratic Party in recent elections. This observation has led some observers, most notably Judis and Teixeira in the book The Emerging Democratic Majority (2004), to advance the claim that demographic changes will create a sustained period of Democratic dominance of national-level politics. The logic of this claim is straightforward. If we assume that groups' voting behavior remains constant and the ratio of groups in the electorate changes the continual increase the number of Democratic leaning ethnic and racial minorities relative to Republican leaning whites will eventually result in the Democratic Party coming to dominate through sheer numerical superiority.

However, this claim rests upon the assumption that groups' voting behavior is likely to remain static. Some observers are skeptical of this possibility. The reasons for doubt are varied, but most objections stem from the assumption imbedded in the emerging majority hypothesis that groups will continue to behave the same in the future as they have in the past. Scholars and political commentators have attacked this assumption from both ends. Many, including Hajnal and Rivera (2014) and Frymer (2010) have noted that whites have become consistently more likely to support Republican presidential candidates over the past 40 years, in part due to the Democratic Party's increasing association with ethnic and racial minority groups. The Republican Party could offset the effects of demographic changes (at least in part) by winning a greater proportion of the white vote. Other observers have questioned whether the Latinos and Asians will continue to support the Democratic Party in future elections (e.g. Trende 2012). The Democrat's New Deal coalition was built largely on the support of urban immigrants from Southern and Eastern Europe. However, these groups became progressively less likely to support the Democratic Party as they assimilated. The trajectory of Southern and Eastern European immigrants' partisanship has obvious parallels with partisanship of modern day Latinos and Asians. While both of these groups are predominantly Democratic voters, the potential for change stems from the observation that Latinos and Asians' partisan attachments are much weaker than those other groups' (Bowler and Segura 2012; Trende 2012). As a result, the Republican Party could make inroads with Latinos and Asians because these groups' partisan attachments are largely inchoate and susceptible to change.

Thus, there are two possibilities: One is that demographic changes continue and that groups continue to behave politically as they have in recent elections. This scenario would lead to the creation of a Democratic advantage. The second is that the Republican Party will be able to offset demographic shifts by engendering a greater amount of support from some segment(s) of the electorate. This could be done through an increase in support (greater turnout or partisan loyalty) among groups that already lean Republican or by making inroads with predominately Democratic groups.

How likely are we to observe a sustained period of Democratic dominance? The plausibility of these two scenarios depends on how political parties react to demographic changes. Here, an examination of the historical record will be revealing. Have demographic changes lead to sustained periods of one-party dominance? Or do parties quickly adjust to changing demographics and sustained periods of partisan control of key institutions a rarity? If 
these periods of sustained partisan dominance are a rarity, the argument that current demographic changes will lead to a sustained period of Democratic dominance becomes less tenable. I attempt to gain leverage on this question in the next section, where I detail theories of party competition in an effort to understand how parties might adapt to changing demographics and move on to present an analysis of partisan advantage in presidential elections since the end of the Civil War.

\section{Models of Party Competition}

Parties must cater their positions to appeal to voters. One of the earliest insights derived from the spatial models of party competition developed by Hotelling (1929), Downs (1957), and Black (1954) was that in two-party competition along a single ideological dimension, the party that captures the median voter will win the election. These one-dimensional models develop a simple expectation about how parties are likely to behave - they are likely to cater their positions with an eye towards winning the median. The expectation that follows from these early theories is that if the median moves, the parties should respond accordingly. Yet, later scholars questioned these one-dimensional depictions of party competition, especially on the grounds that the preponderance of evidence suggests that party positions do not converge to the ideological median but are instead characterized by some degree of polarization.

The more recent spatial models of party competition have dropped the assumption of unidimensionality and instead assume that party competition is characterized by at least two independent dimensions - typically viewed as enduring economic and social cleavages (Schofield, Miller, and Martin 2003; Schofield and Miller 2007; Miller and Schofield 2008). Modeling party competition as two-dimensional is important for several reasons. First, there is no stable equilibrium in two-dimensions. ${ }^{5}$ Second, this lack of a single equilibrium opens the door for parties to pursue a multitude of strategies designed to cut into the opponent's coalition. A multidimensional policy space combined with electoral institutions that restrict party competition to two viable options means that party coalitions are internally divided on at least one dimensions. There are always opportunities for a party to attract disaffected components of the opponent's coalition by appealing to them on the crosscutting dimension (Schattschneider 1960; Miller and Schofield 2008).

There are a number of examples from U.S. political history of candidates expanding their bases of support by appealing to the oppositions' voters on this crosscutting dimensions. Many scholars (e.g. Frymer 2010) have argued that the Republican Party's conservative shift on racial issues initiated by Goldwater and continued by Nixon was a strategic effort to peal away Southern white Democrats who were upset with their party's increasing racial progressivism. While Southern whites generally favored the Democratic Party's economic platform, the Republican Party was able to appeal to this group by emphasizing its newfound conservatism on this crosscutting social/racial dimension. There are other more recent examples. The Reagan campaigns stressed issues relating to moral traditionalism with the goal attracting the support of socially conservative white evangelicals (Nesmith 1993). Recent Democratic candidates have taken the opposite tact, stressing liberal policies on social issues such as gay rights and stem cell

\footnotetext{
${ }^{5}$ There is no potentially no median in two dimensions for parties to converge on. This helps to explain why the parties differentiate themselves ideologically, often greatly so.
} 
research in an effort to attract socially moderate Republicans who were increasingly disaffected by the Republican Party's social conservatism.

The multidimensional nature of American politics opens the door for losing parties to cut into the opposing party's coalition by attracting disaffected supporters. There are numerous examples of parties adjusting their positions and attracting new sources of electoral support. As such, we should never expect losing political parties to be "out of the game" for too long, given that the winning party's coalition is internally divided on one of the two dimensions. It is this fundamental instability that potentially helps explain why presidential elections are so highly competitive.

In the next section I assess whether this conception of political parties as constantly adjusting (and as a result, competitive) is consistent with the empirical record. Here, I present an empirical model that establishes turnover in partisan control is frequent in American presidential politics. The results will help to shed light on the plausibility of the two scenarios outlined in the previous section. The odds of a prolonged period of Democratic dominance are much higher if sustained periods of partisan control are the norm.

\section{Competitive Equilibrium and Partisan Cycles}

One of the most remarkable features of American presidential elections is the level of partisan stability. Parity is the norm in presidential politics, at least over the long-term. Bartels $(1998,291)$ noted that, "the popular vote margin never strays very far or very long from the competitive equilibrium represented by an even partisan division of the vote." Figure 1 displays the Democratic percentage of the two-party vote for every presidential election since the end of the Civil War. The pattern of ebbs and flows in Figure 1 illustrates that any advantage one party is able to gain over its rival eventually erodes and an alternation of power occurs. Periods of Republican dominance, such as the series elections spanning 1920 and 1932, are often followed by periods of Democratic success. Electoral majorities are fleeting.

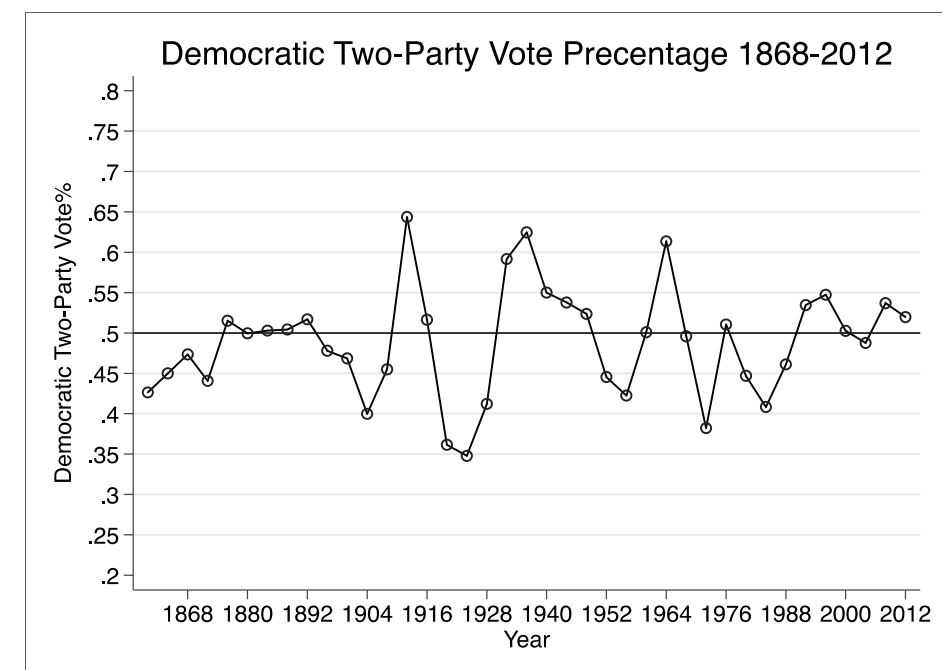

Figure 1: Democratic percentage of the two-party presidential vote 1868-2012 
What is perhaps even more interesting is that changes in the Democratic and Republican shares of the two-party vote are not random - each party's share of the vote tends to regress back towards the equilibrium. I demonstrate this by regressing the change in the Democratic share of the two-party vote from time $t-1$ to time $t$ on the Democratic share of the vote at time $t-1$ for every election year between 1868 and 2012 (this model replicates and extends the one employed by Bartels 1998, 292). This model tests whether how well the Democratic Party's past performance predicts its future performance, if at all. In this model, the intercept records the equilibrium (the expected vote margin absent other influence), while the coefficient on the lagged Democratic two-party vote records the speed of the reversion back to the equilibrium (McDonald and Best 2006). Table 2 displays the results of this analysis.

\begin{tabular}{l|cc}
\hline & 1 Election Lag & 2 Election Lag \\
\hline Democratic Margin $t-1$ & $-0.66^{* * *}$ & $-0.48^{* * *}$ \\
& $(0.16)$ & $(0.15)$ \\
Democratic Margin $t-2$ & $\sim$ & $-0.54^{* * *}$ \\
& & $(0.14)$ \\
Constant & -0.005 & -0.01 \\
& $(0.01)$ & $(0.01)$ \\
Observations & & \\
R-squared & 37 & 37 \\
\hline \multicolumn{2}{c}{ Standard Errors in Parentheses *** p<0.001 }
\end{tabular}

Table 2: Change in Democratic Two-Party Vote Margin Regressed on Previous Democratic Two-Party Vote Share $1868-2012$

The equilibrium (intercept) of this model is a vote margin of zero, or in other words, an even 50:50 distribution of the two-party vote. The coefficient for the Democratic vote margin is -.66 and statistically significantly different from zero. The winning party can expect to retain a third of the previous margin $(1-.66=.34)$ in the next election. If the coefficient for the Democratic Party's vote margin in the previous election were negative one, then this would imply an immediate reversion. For example, if the Democratic vote margin were 5-points at time $\mathrm{t}-1$, the expected Democratic vote margin at time $\mathrm{t}$ is $\left(5^{*} .34\right)$, which equals an expected vote margin of 1.7-percentage points. This finding generates two implications. Firstly, the trend is not a "random walk," where the Democratic two-party vote share is equally likely to increase or decrease from time t-1 to time t (Stokes and Iversen 1962, 167; Robbins and Norpoth 2010, 322). Rather, the expectation is that the winning party will perform worse in the next election - the long-term trend is that the vote margin will return towards the equilibrium, which is an even partisan distribution of the vote (McDonald and Best 2006, 372). Secondly, a coefficient of -.66 implies that the reversion back to this equilibrium point is not immediate - a party can expect to retain a portion of its previous vote margin. While the trend is for the system to equilibrate, the 
non-immediate nature of the reversion opens up the possibility for partisan cycles. If partisan cycles are a regular occurrence then the proposition of an era of sustained Democratic dominance in the future becomes more likely.

The existence of partisan cycles has been well established on the Congressional level. Robbins and Norpoth (2010, 321-324) demonstrated that a competitive equilibrium exists on the Congressional level (the authors analyzed Congressional elections spanning 1828-2004), but the return to this equilibrium point is slow, with long periods of sustained partisan control. The evidence suggests that the system balances over the long-term-but political parties are sometimes able to gain an advantage that lasts for several decades. ${ }^{6}$ While the analysis presented in Table 1 demonstrated that the long-term equilibrium is an even partisan distribution of the vote, it is possible that the equilibrium has deviated from 50:50 during certain eras. This possibility is consistent with the political cycles literature (e.g. Meffert, Norpoth and Ruhil 2001; Norpoth and Rusk 2007; Merril, Grofman and Brunell 2008).

The question here is: have meaningful political cycles occurred on the presidential level? Or does the equilibrium fail to diverge from 50:50, even over the short(er) term? I test this possibility by replicating the model in Table 2 across each possible ten-election subsample spanning 1868 though 2012. The first subsample spans 1868-1904 while the last includes the ten elections between 1976 and 2012. The ten-election timeframe included in these estimates represents roughly a generation (corresponding to Schlesinger's famous 36-year span). This setup allows me to test whether one party is able to maintain an electoral advantage that spans the majority of the average voter's political lifespan. The key question is whether the equilibrium (intercept) ever becomes significantly different from zero? If the intercept is distinguishable from zero, vote outcomes are regressing back towards an equilibrium that favors one party over the other. Table 3 displays the results.

\footnotetext{
${ }^{6}$ It is important to note that the dynamics of Congressional elections differ from those of presidential elections in several important ways. The effects of incumbency, uncontested districts, differences in candidate quality and state party systems all likely contribute for the less frequent reversal of partisan control compared to what is observed on the presidential level.
} 


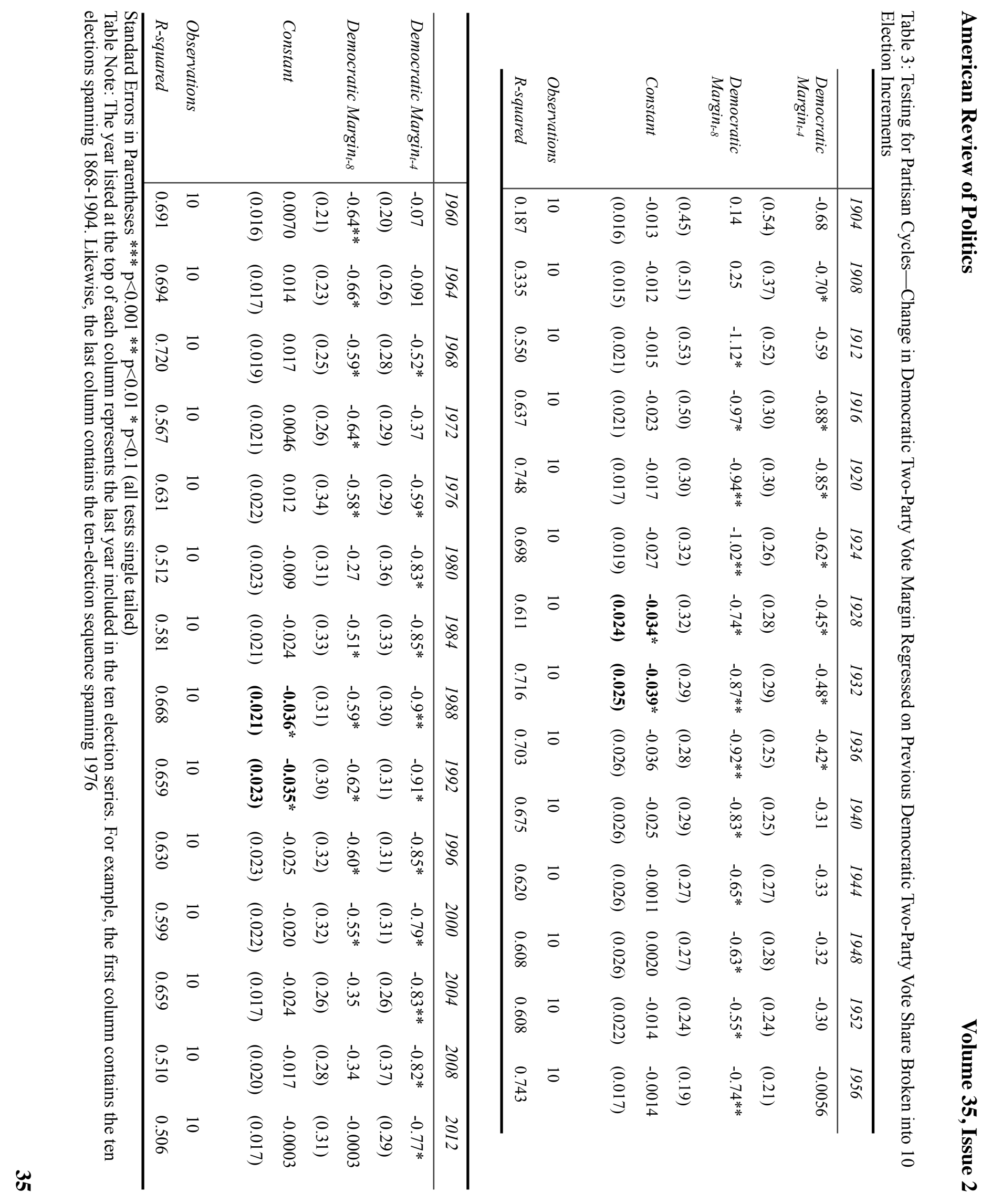


I draw two conclusions from Table 3. The first is that the equilibrium generally remains close to 50:50, even when I limit the analysis to 10-observation subsets. In most eras of American political history, parity (in terms of the two-party presidential vote) is the norm. However, this is not to say that political parties are always unable to gain an advantage that spans a generation. In two instances, the Republican Party managed to gain an advantage where the equilibrium point drifted in its favor. These two periods of time, 1892-1932 and 1952-1992 conform to what are considered Republican dominated eras (Petrocik 1981, 52-53; Frymer 2010, 3-7). The equilibrium moved towards a 53.5-46.5 split in favor of the Republicans in both instances, before gradually regressing back towards an even distribution. ${ }^{7}$ The Democrats have never managed to gain a statistically significant electoral advantage, although the equilibrium did drift in the Democrats' favor during the New Deal Era, approaching but not reaching traditional levels of significance. The takeaway is straightforward; parity is the norm, but on occasion political parties have been able to establish significant electoral advantages that last for the period of several decades, yet the party system tends to revert back to an even 50:50 distribution over the long-term. ${ }^{8}$

The long and short-term dynamics of the party system raise some interesting questions about the future of American politics. Are demographic changes that favor the Democrats going to bring about a sustained period of Democratic advantage similar to the advantage the Republican Party enjoyed between 1892-1932 and 1952-1992? Or will the forces restoring the equilibrium (which is reflected by the negative coefficient on the lagged vote margin) quickly restore parity? I begin to address these questions in the next section, where I simulate how demographic changes will alter the partisan balance in the absence of any forces that systematically alter voting behavior.

\section{A Simulation that Assumes Group Behavior Remains Constant}

What will happen if the ratio of groups continues to shift but voting behavior remains stable? I construct a series of Monte Carlo simulations to assess this possibility. Monte Carlo simulations are an ideal tool for assessing the Republicans' probability of winning national elections given varying assumptions about future group size, Republican loyalty, and turnout (Robinson et al. 2015). A Monte Carlo simulation randomly generates a sample of data from a defined population with an assumed data generating process (Carsey and Harden 2014, 4). In my simulations, the defined population is the electorate. In this set of simulations, I allow the ratio of groups to change but assume voting behavior remains stable in an effort to simulate the effects of future demographic changes.

\footnotetext{
${ }^{7}$ It is also worth noting that the speed of the reversion back to the equilibrium varies considerably, as does the overall model fit. The speed of reversion is fastest in the mid $20^{\text {th }}$ century and slowest in the early $20^{\text {th }}$ century. Also, the fit of these models is poor in the period of political flux that immediately followed the Civil War and Reconstruction, suggesting that other forces not observed in other eras of American politics were affecting vote outcomes during this time period. The model fit gets progressively better following this period.

${ }^{8}$ The evidence suggesting that election outcomes return to a competitive equilibrium led Stokes and Iversen to speculate that there are "forces at work restoring party competition." The authors posited that there are a number of potential processes that could explain why election outcomes equilibrate, including vacillations in the public's ideological mood, voters punishing the incumbent for poor economic performance, and the difficulties associated with maintaining a majority coalition with diverse preferences, among others.
} 
Each simulation has two moving parts:

1) Each group's proportion of the electorate - which is a function of both group size and turnout

2) Each group's level of Republican loyalty

I incorporate variance surrounding each group's share of the electorate and Republican loyalty. The reasons for including this variation are straightforward. Parties have groups of core supporters that they can count on from election to election, however, short-term electoral forces such as the state of the economy, incumbency, and other candidate specific dynamics play an important role in the pushing elections in favor of one side or another (Stokes 1962; Lewis-Beck 1990; Nadeau and Lewis-Beck 2001; Erikson, Stimson and MacKuen 2002; Erikson and Wlezien 2012). Adding variance around each group's mean-level of Republican loyalty creates a distribution of potential levels of Republican support, which account for short-term forces and allow me to assess how the Republican Party's likelihood of winning elections varies according to whether patterns of group support are above or below their established averages.

I adopt a similar approach for dealing with variations in turnout and group size. Whites constituted 72 percent of the electorate in 2012 and I assume that whites will constitute three percentage points less in each subsequent election, which is an continuation of the linear decline in the white proportion observed since the early 1990s. This assumption is based on projections from the Census Bureau. I assume that the African America percentage of the electorate will remain stable at 12 percent. I posit a 3-percentage point increase in the Latino and Asian proportion of the population in each subsequent election cycle - which is consistent with the current trend and census projections. ${ }^{9}$ I account for variation in turnout by assuming variance around each group's share of the electorate. Including this variance around each group's proportion of the electorate accounts for the possibility that one group's turnout is particularly high or low relative to the established patterns or that future demographic changes depart from the Census Bureau's projections. ${ }^{10}$

So how much variance should I assume around each group's level of Republican support and each group's projected share of the electorate? I utilize each group's observed variance in voting behavior (displayed in the final column of Table 1) to ground my estimates. Since 1980, the average level of white, African American, Latino/Asian (and others) Republican support has been $61,6.3$, and 36.4 respectively. The standard deviations around these means are 4.3, 4.47, and 8.17. I adopt a similar approach for estimating the variance surrounding each group's share of the electorate. The standard deviation surrounding the change in each group's proportion of

\footnotetext{
${ }^{9}$ See: http://www.census.gov/population/projections/data/national/2012/summarytables.html. These projections largely mirror the current trend. From 1992 and 2012 the white proportion of the electorate declined from 87 to 72 percent, an average decrease of 3 percentage points per election cycle. Both the Latino and Asian proportion of the electorate has increased fivefold since 1992 (2 percent in 1992 to 10 percent in 2012 for Latinos and 1 percent to 5 percent for Asian Americans) The African American percentage of the electorate (and overall share of the population) has been very consistent, averaging 12 percent over the last four election cycles.

${ }^{10}$ As many readers will undoubtedly note, Latinos and Asians make up a smaller proportion of the electorate relative to their total share of the population. One reason for this gap is that Latino (48\%) and Asian (47.3) turnout lags far behind that of whites (64\%) and African Americans (66\%). Obviously, the Latino and Asian proportion of the electorate will increase at a more rapid pace if these groups' turnout rates increase relative to the rates of whites and blacks.
} 
the electorate is 1.16. The interpretation of these standard deviations is that 68 percent of the 10,000 Monte Carlo simulations draw loyalty and group size parameters that are within $+/$ - one standard deviation of the mean. For example, the mean level of white Republican loyalty is 61 percent and the standard deviation is 4.3 , which implies that in 68 percent of the Monte Carlo simulations the level of white Republican loyalty is between 65.3 and 56.7 . White loyalty falls outside of these bounds in the other 32 percent. $^{11}$

Incorporating variance around these mean levels of group Republican loyalty allows me to assess questions such as: How will the Democratic Party fare in an election with lower than average African American turnout and high Latino Democratic loyalty? What are the Republican Party's odds of winning if white turnout is below average? There are countless potential combinations of levels of group loyalty and turnout. Each individual Monte Carlo simulation takes random draws from these distributions of potential levels of partisan loyalty and turnout. Running 10,000 random simulations allows me to assess the Democratic and Republican odds of victory given all sorts of variations. An advantage of this approach is that it allows me to calculate the overall probability of a Republican victory directly using the number of scenarios in which their vote exceeds 50\%. In addition, I can assess whether the Republican Party could still manage to win in a "good Republican year" in spite of demographic changes.

I use these established patterns of group behavior to construct a baseline set of simulations. To do this, I assume that white, African American and Latino Republican loyalty will remain at their previously established thirty-year average over the course of the next 20 years. I present the results of these simulations in Figure 2. The results of these simulations demonstrate that if group preferences remain unchanged the electoral equilibrium will continue to drift in favor of the Democrats. The simulations reveal that both parties would have had a roughly equal chance to win the 2012 election (the Democrats won 52 percent of the simulated elections) if group loyalty and turnout rates remained at their historical averages. However, Obama was able to win comfortably by engendering higher than average turnout and loyalty from virtually every ethnic minority group. ${ }^{12}$ However, this level of parity fails to hold going forward. The equilibrium quickly moves in favor of the Democrats. The Democrats win 64 percent of simulations in 2016, this number jumps to 76 percent in 2020, 85 percent in 2024, 91 percent in 2028 and topping out at 95 percent in 2032. An implication of these findings is that if behavior remains consistent with historical patters, the Republicans will be increasingly only be able to win when all groups' levels of Republican loyalty are at near historical highs. Moreover, the Republican Party is increasingly reliant on favorable turnout patterns (instances where white turnout is high and minority turnout is low) the more the ratio of the groups change. The likelihood of a Republican victory becomes increasingly remote even working under scenarios where it gets higher than average turnout and support from all demographic groups.

\footnotetext{
${ }^{11}$ I assume the variance surrounding these mean levels is normally distributed.

${ }^{12}$ See the Brookings Institute's incisive report on voter turnout and demographic change: http://www.brookings.edu/ research/papers/2013/05/10-election-2012-minority-voter-turnout-frey
} 

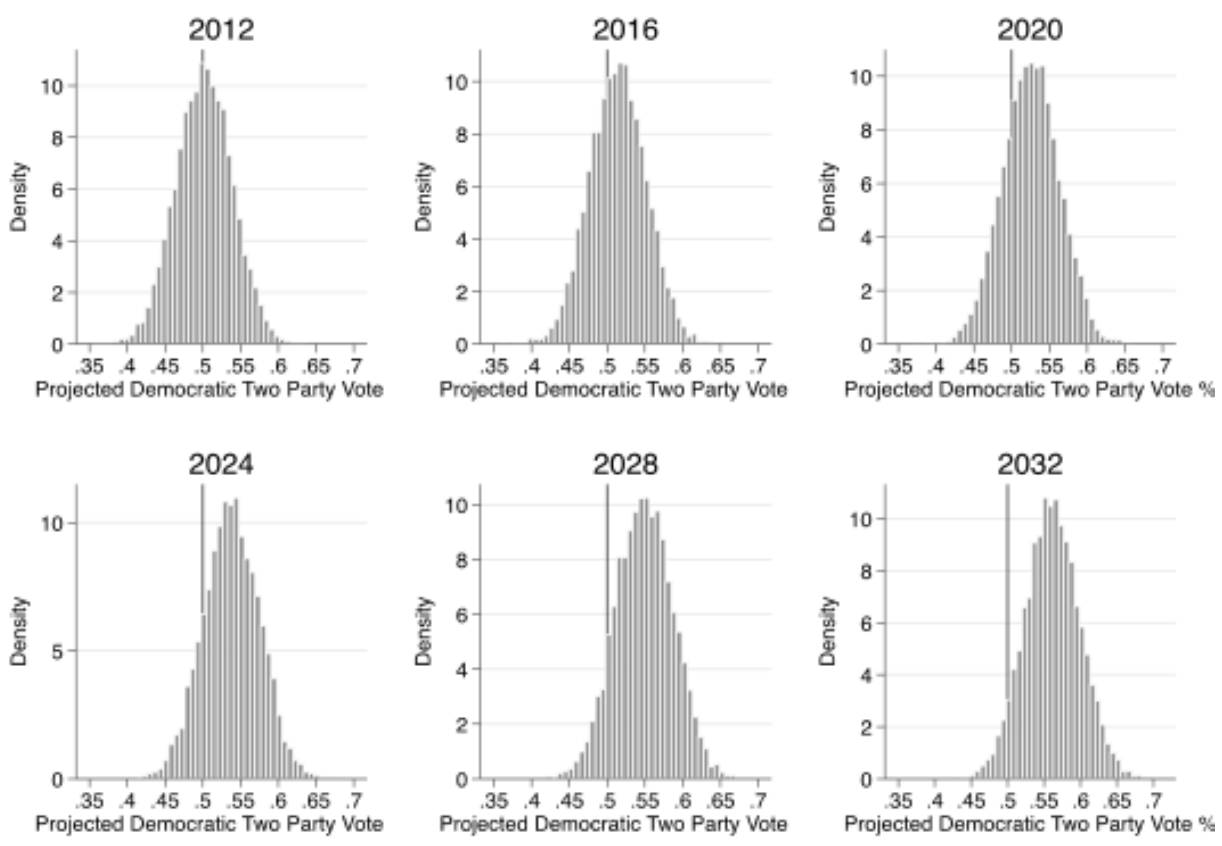

Figure 2: Projected Republican share of the two-party vote - assuming expected demographic changes and no change in group partisan splits

These simulated election outcomes raise the possibility that the national-level equilibrium will drift in the favor of the Democratic Party over the coming decades. There have been at least two instances in American history where the electoral equilibrium drifted away from 50:50 over a span of ten elections. This finding suggests that we could observe an era where the equilibrium significantly moves in the Democratic Party's favor, similar to the two other periods in U.S. history (1892-1932 and 1952 -1992), where the electoral equilibrium drifted in favor of the Republican Party (as reflected by the significant intercept terms in Table 2). ${ }^{13}$

However, it is important to note that the purpose of these simulations is not to show that the electoral equilibrium will inevitably drift in favor of the Democrats. Rather, the purpose of these simulations is to demonstrate that voting behavior must change for the competitive equilibrium to hold. Given the party system's propensity to balance, it is reasonably likely that the pro-Democratic effect of demographic changes will be counteracted by behavioral changes that work to pull the partisan equilibrium back towards an even 50:50 distribution. The key question then becomes what type of changes would be sufficient to maintain the partisan balance?

\footnotetext{
13 Yet, even during these periods the disadvantaged party has managed to win elections. Woodrow Wilson won two consecutive elections, which interrupted a period of sustained Republican dominance spanning 1896-1932.

Likewise, Jimmy Carter was able to interrupt a string of Republican victories that otherwise spanned 1968 through 1988.
} 
On the surface, there appears to be several different ways that the party system could equilibrate. One path forward is for the Republicans to win a greater proportion of the white vote, which would create a party system polarized along ethnic and racial lines akin to levels typically observed in the American South. Several political commentators, most notably Sean Trende (2013), have advanced the argument that this outcome is plausible. ${ }^{14}$ A second possibility is for the Republican Party to maintain its level of support among whites and increase support among ethnic and racial minorities. Political scientists Alan Abramowitz and Ruy Teixeira (also see Teixeira and Judis 2004) have argued that the Republican Party will be relegated to a permanent minority if they are not able to bring more non-whites, especially Latinos, into its coalition. ${ }^{15}$ These two potential paths forward raise the question: what is the magnitude of changes that will have to occur to maintain the competitive equilibrium? In the next section, I explore what changes in voting behavior will be sufficient to maintain the competitive equilibrium.

\section{Exploring Potential Paths Towards Electoral Balance}

The core takeaway from these simulations is that the Republican Party is going to need additional sources of support to remain competitive. Fortunately for the Republican Party, the multidimensional nature of American political competition means that some segment of the Democratic coalition is potentially dissatisfied and a potential source of future Republican support. As I will show, the Republican Party can maintain a roughly equal chance of winning through engendering relatively modest shifts in voting behavior. However, there are several possible avenues through which balancing could occur. I detail these possibilities here.

One path is for the Republican Party to win a greater proportion of the white vote. Whites have become increasingly Republican over the past 30 years (Bartels 2006, 209), and there is reason to believe that whites might become even more likely to support Republican candidates in the coming decades. Recent experimental evidence provided by Maureen Craig and Jennifer Richeson (2014; also see Hajnal and Rivera 2014) has demonstrated information regarding the country's changing demographic composition heightened whites' perception of group identity and prompted whites to express less favorable opinions of Latinos, blacks and Asians. Given that whites will likely become increasingly cognizant of shrinking group size, it is plausible that white group identity will become an increasingly important determinant of political attitudes and behaviors, leading to an increase in white political cohesion. The end result of this process would be an electorate even more polarized along racial lines than it was in 2012. The question here is: what percentage of the white vote will the Republican Party have to win in order to maintain a roughly equal chance of winning?

To answer this question, I assume that both parties will maintain and equal chance of winning and then back out the necessary level of white Republican loyalty. I assume that the white proportion of the electorate will shrink by three percentage points in each election and the

\footnotetext{
${ }^{14}$ Although it should be noted that Trende does not necessarily advocate for the Republican Party to purse an electoral strategy designed to induce further levels of racial and ethnic polarization.

15 See Abramowitz and Teixeira's essay at: http://www.centerforpolitics.org/crystalball/articles/is-doubling-downon-white-voters-a-viable-strategy-for-the-republican-party/
} 
Republican loyalty of African Americans and Latinos/Asians will remain fixed at the estimated baseline levels, 6.3 and 36.4 respectively. The second column in Table 4 displays the estimated level of white loyalty the Republican would need to achieve. On average, Republican candidates will have to win a 1.65-point greater share of the white vote in each subsequent election to remain electorally competitive over the next 20 years. However, this average belies the nonlinear pace of the necessary change. For instance, in 2016, the Republican candidate will have to increase the Republican share of the white vote by 1 percentage point from 2012 in order to offset the changing group ratios. This number increases to 1.3 points between 2016 and 2020 and 1.6 points between 2028 and 2032. The need for this larger increase in white Republican loyalty arises as a function of the fact that whites will constitute a smaller proportion of voters in each election cycle. Overall, the Republican Party will need to gain almost 7 percentage points more support among whites (60.3 to 67.1) over the next 20 years to maintain an expected even distribution of the vote.

\begin{tabular}{c|c|c}
\hline Year & White Republican Support & Latino/Asian Republican Support \\
\hline 2012 & 60.3 & 33.1 \\
2016 & 61.4 & 37.7 \\
2020 & 62.7 & 40.9 \\
2024 & 64.0 & 43.4 \\
2028 & 65.5 & 45.3 \\
2032 & 67.1 & 46.8 \\
\hline
\end{tabular}

Table 4. Percentage of the White and Latino/Asian Votes Needed to Maintain a 50:50 Equilibrium Assuming Other Groups' Behavior Remain Constant

One way that the Republicans could gain a greater share of the white vote is to perform better among white women. Many political observers have noted the presences of a persistent "gender gap" in American's partisan preferences, as women have been considerably more likely than men to support the Democratic Party. The average gender gap in the last three elections among whites has been 6 points. ${ }^{16}$ There has not always been a gender divide in American politics; rather the gender gap only really emerged in force during the 1980s (Kaufmann and Petrocik 1999, 864; Zingher 2014, 8). The fact that the gender gap has not been a permanent facet of American politics suggests that the Republican Party is capable of improving its performance among white women. If the Republican Party were able to bring white women's level of Republican support on par with that of men's it would increase the Republican share of the white vote by 3 percentage points. The Republican Party could go a long way to offsetting unfavorable political consequences of demographic change by erasing the gender gap.

It is also possible to imagine a second path where Republicans maintain the partisan balance by attracting greater support from Latinos and Asians. Many within the Republican Party

\footnotetext{
16 These estimates come from Voter News Service National exit polling.
} 
have advocated for making a greater push to attract Latino and Asian voters, claiming that obtaining a greater proportion of the Latino and Asian vote will be necessary to compete in future elections. There is some evidence to suggest these groups might be poised to become more Republican. Over the course of generations, members of groups of recent immigrant heritage often become increasingly less distinct from the native population. This pattern of "ethnic attrition" often leads third and fourth generation individuals to stop identifying as members of ethnic minority groups when asked on survey instruments (Duncan and Trejo 2011, 604-606).

This is the story of many Southern and Eastern European immigrant groups-first and second generation immigrants were politically and socially distinctive from the native population, but third and fourth generation children of immigrants become increasingly indistinguishable as a result of increased rates of intermarriage and decreased residential segregation. Research has demonstrated that first and second generation Latino immigrants have considerably different political orientations, so an increase in Latino and/or Asian Republican partisanship is not out of the question, especially as Latinos and Asians become more economically and socially integrated into American society (Hajnal and Lee 2011; Trende 2012, 148-150).

The question is: "how much more of the Latino and Asian vote will Republican candidates have to win in order to remain competitive?" Assuming that Republicans maintains their current level of support among whites and African Americans, the Republican Party will have to increase its share of the Latino and Asian votes by 11 percentage points (moving from an average of 36.4 percent since 1980 to 47.7 percent in 2032) in order to maintain the electoral balance. These estimates are displayed in the third column of Table 5.

In both of these aforementioned scenarios, the Republican Party would require a moderately sized change in voting behavior to remain competitive. It is important to note that the two scenarios outlined in this section involve two extremes; each scenario assumes that one group's voting behavior will change while other groups' behaviors remain fixed. A more moderate path forward could occur as a result of several of smaller shifts. The Republican Party could remain competitive though a combination of smaller increases in support from whites and Latinos/Asians. A joint shift by both groups in favor of the Republicans could produce the same aggregate level effect without requiring as large a shift in the behavior of either group. This is a third possible way that the equilibrium could maintain and this scenario represents a middle path between the two more extreme possibilities. The possibility that the Republican Party will remain competitive in spite of changing demographics seems plausible when cast in these terms. 


\section{Discussion and Conclusions}

The findings in this paper are important for two reasons. The first reason is that they demonstrate fears that the Republican Party will be reduced to a permanent electoral minority are likely overblown. I have demonstrated there are at least two paths the Republican Party could take to remain competitive over the next several decades (as well a numerous paths that are the combination of the two extreme scenarios laid out here), and neither of them requires a wholesale change of groups' voting behavior. The second, and perhaps more important conclusion, is that the competitive equilibrium American party systems is resilient. The historical evidence I have assembled demonstrates parity is the norm in American presidential politics. The analysis in the second half of this essay helps to demonstrate why this equilibrium might be so resilient - a combination of several relatively moderate changes in voting behavior could be enough to allow the Republican Party to remain competitive for the foreseeable future. The Republicans' electoral dilemma, which is certainly pressing, is by no means insurmountable.

One point that deserves mention is that parties do not just increase their level of support automatically - making inroads among groups that are loyal to the opposition often requires years of hard work. At the end of the day, voters care about policy. If the Republicans want to make serious inroads among Latinos, Asians, women, or other groups this will likely require a shift in policy positions. This could involve advocating immigration policies with greater appeal to recent immigrant groups, or adopting a platform that has greater appeal among women, and/or appealing to these critical groups any number of other types of policy offerings. ${ }^{17}$ The key takeaway here is that the competitive equilibrium is maintained through political parties making the necessary adjustments to changing conditions. If parties failed to make these types of adjustments the competitive equilibrium would fail to hold.

Overall, I established that a competitive equilibrium that characterizes the American party system, which is consistent with other recent analyses of the dynamics of U.S. electoral politics. This finding implies that if the expected distribution of the vote is to remain at 50:50, the Republican Party must find new sources of electoral support to offset demographic changes. I identified several sets of relatively modest changes in white and/or Latino/Asian partisan loyalty sufficient to maintain the electoral balance. Thus, it appears that the Republican Party has a realistic path to remain electorally viable in spite of changing demographics.

\footnotetext{
${ }^{17}$ See Nate Silver's analysis on the potential effects of the passage of comprehensive immigration reform on Latino and Asian voting behavior: http://fivethirtyeight.blogs.nytimes.com/2013/04/30/how-immigration-reform-anddemographics-could-change-presidential-math/
} 


\section{Bibliography}

Andersen, K. 1979. The Creation of a Democratic Majority, 1928-1936. Chicago, IL: University of Chicago Press.

Axelrod, R. 1972. Where the Votes Come From: An Analysis of Electoral Coalitions, American Political Science Review, 66(1): 11-20

Bartels, L. 1998. Electoral Continuity and Change, 1868-1996. Electoral Studies, 17(3): 01-326.

Bartels, L. 2006. What's the Matter with 'What's the Matter with Kansas,' Quarterly Journal of Political Science, 1: 210-226.

Black, D. 1958. The Theory of Committees and Elections. Cambridge, UK: Cambridge University Press.

Bowler, S. \& Segura, G.M. 2012. The Future is Ours: Minority Politics, Political Behavior, and the Multiracial Era of American Politics. Washington DC: Congressional Quarterly Press.

Budge, I., Keman, H., McDonald, M.D. \& Pennings P. 2012. Organizing Democratic Choice, Party Representation Over Time. Oxford: Oxford University Press.

Carsey, T. \& Harden, J. 2014. Monte Carol Simulation and Resampling Methods for the Social Sciences. SAGE.

Craig, M. \& Richeson, J. 2014. More Diverse Yet Less Tolerant, How the Increasingly Diverse Racial Landscape Affects White Americans' Racial Attitudes, Personality and Social Psychology Bulletin, doi:10.1177/0146167214524993

Downs, A. 1957. An Economic Theory of Democracy. New York, NY: Harper and Row.

Duncan, B. \& Trejo, S.J. 2011. Tracking Intergenerational Progress for Immigrant Groups: The Problem of Ethnic Attrition, American Economic Review, 101(3): 603-608.

Erikson, R.S. \& Wlezien, C. 2012. The Timeline of Presidential Elections: How Campaigns Do (and do not) Matter. Chicago, IL: University of Chicago Press.

Erikson, R.S., Stimson, J. \& MacKuen, M. 2002. The Macro Polity. New York, NY: Cambridge University Press.

Frymer, P. 2010. Uneasy Alliances: Race and Party Competition in America. Princeton, NJ: Princeton University Press. 
Hanjal, Z. \& Lee, T. 2011. Why Americans Don't Join the Party: Race, Immigration and the Failure (of Political Parties) to Engage the Electorate. Princeton, NJ: Princeton University Press.

Hajnal, Z \& Rivera, M 2014. Immigration, Latinos, and White Partisan Politics: The New Democratic Defection, American Journal of Political Science, 58(4): 773-789.

Hotelling, H. 1929. Stability in Competition. The Economic Journal, 39: 41-57.

Kaufmann, K. \& Petrocik, J. 1999. The Changing Politics of American Men: Understanding the Sources of the Gender Gap, American Journal of Political Science, 43(3): 864-887.

Lewis-Beck, M. 1990. Economics and Elections: The Major Western Democracies. Ann Arbor, MI: University of Michigan Press.

Lewis-Beck, M. \& Nadeau, R. 2001. Economic Voting in U.S. Presidential Elections, Journal of Politics, 63(1): 159-181.

Mayhew, D.R. 2011. Partisan Balance: Why Political Parties Don't Kill the U.S. Constitutional System. Princeton, NJ: Princeton University Press.

McDonald, M.D. \& Best, R. 2006. Equilibria and Restoring Forces in Models of Vote Dynamics, Political Analysis, 14: 369-392.

Meffert, M.F., Norpoth, H. \& Ruhil, A. 2001. Realignment and Macropartisanship, American Political Science Review, 95(4): 953-962.

Merrill, S., Groffman, B. \& Brunell, T. 2008. Cycles in American National Electoral Politics, 1854-2006: Statistical Evidence and an Explanatory Model, American Political Science Review, 102(1): 1-17.

Miller, G \& Schofield, N. 2008. The Transformation of the Republican and Democratic Party Coalitions in the U.S. Perspectives on Politics, 6(3): 433-450.

Nesmith, B. 1993. The New Republican Coalition: the Reagan Campaigns and White Evangelicals. Peter Lang Pub Incorporated.

Norpoth, H. \& Rusk, J.G. 2007. Electoral Myth and Reality: Realignments in American Politics, Electoral Studies, 26(2): 392-403.

Petrocik, J. 1981. Party Coalitions: Realignments and the Decline of the New Deal Party System. Chicago, IL: University of Chicago Press. 
Pew Hispanic Center, 2011. 2011 National Survey of Latinos. http://www.pewhispanic.org/ category/datasets/?download $=19140$

Robbins, S.M. \& Norpoth, H. 2010. Balance or Dominance? Party Competition in Congressional Politics, Political Research Quarterly, 63(2); 316-327.

Robinson, G., Krasno, J., Zingher, J. and Allen, M. 2015. Creating a Racially Polarized Electorate: the Partisan Fallout of Immigration Politics in Arizona and California, Politics, Groups, and Identities, http://www.tandfonline.com/doi/full/10.1080/21565503.2015.1050417

Schattschneider, E.E. 1960. The Semisoverign People: A Realist's View of Democracy in America. Boston, MA: Wadsworth.

Schlesinger, A.M. Jr. 1999. The Cycles of American History. New York, NY: Mariner Books

Schofield, N. \& Miller, G. 2007. Elections and Activist Coalitions in the United States. American Journal of Political Science, 51(3): 518-531.

Schofield, N., Miller, G. \& Martin, A. 2003. Critical Elections and Political Realignments in the USA: 1860-2000. Political Studies, 51: 217-240.

Stokes, D. 1962. Party Loyalty and the Likelihood of Deviating Elections. Journal of Politics, 24(4): 689-702.

Stokes, D. \& Iversen, G. 1962. On the Existence of Forces Restoring Party Competition, Public Opinion Quarterly, 26(2): 159-171.

Teixeira, R. \& Judis, J. 2004. The Emerging Democratic Majority. New York, NY: A Lisa Drew Book/Scribner.

Tichenor, D. 2009. Dividing Lines: The Politics of Immigration Control in America. Princeton, NJ: Princeton University Press.

Trende, S. 2012. The Lost Majority: Why the Future of Government is Up for Grabs-and Who Will Take It. New York, NY: Palgrave-MacMillan.

Trende, S. 2013. Are we in Electoral Realignment? In Barack Obama and the New America: The 2012 Election and the Changing Face of Politics, Ed. Larry J. Sabato. Lanham, Maryland: Rowman \& Littlefield Press.

Wlezien, C. 2000. An Essay on 'Combined' Time Series Processes, Electoral Studies, 19(1): 77-93. 
Wlezien, C. \& Erikson, R.S. 2002. The Timeline of Presidential Election Campaigns, Journal of Politics, 64(4): 969-993.

Zingher, J.N. 2014. An Analysis of the Changing Social Bases of America's Political Parties: 1952-2008, Electoral Studies, 35: 272-282. 